\title{
Profil Diare di Ruang Rawat Inap Anak
}

\author{
Sulaiman Yusuf \\ Bagian Ilmu Kesehatan Anak Fakultas Kedokteran Universitas Syiah/Rumah Sakit Umum Daerah \\ Dr. Zainoel Abidin, Banda Aceh
}

\begin{abstract}
Latar belakang. Data tentang profil pasien diare pada anak di Rumah Sakit - Rumah Sakit pusat rujukan belum lengkap termasuk di Rumah Sakit Umum Daerah Dr. Zainoel Abidin (RSUDZA) Banda Aceh.

Tujuan. Mengetahui profil pasien diare di ruang rawat inap anak RSUDZA Banda Aceh.

Metode. Studi retrospektif dilakukan pada pasien diare di ruang rawat inap anak RSUDZA Banda Aceh, tanggal 1 Juli 2009 s/d 30 Juni 2010. Pencatatan dilakukan tentang umur, jenis kelamin, jenis diare, derajat dehidrasi, status gizi, penyakit penyerta, dan lama rawatan kemudian disajikan secara deskriptif.

Hasil. Jumlah pasien rawat terlama periode penelitian 1279 anak, sedangkan pasien diare 104 anak (8,1\%). Proporsi diare berdasarkan umur yaitu 1 bulan $-<2$ tahun 73,1\%, $2-<5$ tahun 18,3\%, dan $5-16$ tahun $8,6 \%$. Jenis diare yaitu, diare akut $80,8 \%$, diare melanjut $12,5 \%$ dan diare persisten $6,7 \%$. Derajat dehidrasi yaitu, tanpa dehidrasi $26 \%$, dehidrasi ringan-sedang $62,5 \%$, dan dehidrasi berat $11,5 \%$. Status gizi yaitu, obesitas 5,8\%, gizi lebih 2,9\%, normal 44,2\%, gizi kurang 38,5\%, dan gizi buruk 8,6\%. Pasien diare disertai penyakit penyerta 55,8\% yaitu gizi kurang 68,9\%, gizi buruk 15,5\%, bronkopneumonia $6,9 \%$, tonsilofaringitis akut 3,5\%, kejang demam kompleks 3,5\%, dan varisela 1,7\%. Lama rawatan 90,4\% kurang dari 5 hari.

Kesimpulan. Kelompok umur terbanyak pasien diare $<2$ tahun, diare persisten 6,7\%, diare dengan dehidrasi berat $11,5 \%$, dan lama rawat $\geq 5$ hari $9,6 \%$, serta penyakit penyerta terbanyak adalah gizi kurang dan buruk, serta bronkopneumonia. Sari Pediatri 2011;13(4):265-70.
\end{abstract}

Kata kunci: diare, profil

$\mathrm{P}$ enyakit diare masih menjadi masalah kesehatan masyarakat di negara berkembang termasuk di Indonesia dan merupakan salah satu penyebab kematian dan kesakitan tertinggi pada anak, terutama usia di bawah 5

\footnotetext{
Alamat korespondensi:

Dr. Sulaiman Yusuf, SpA. Divisi Gastroentero-Hepatologi BIKA FK Unsyiah/RSUDZA Banda Aceh, Jl. Tgk Daud Beureueh No. 108, Banda Aceh, HP 0811683194, email: sly_adan@yahoo.com
}

tahun. ${ }^{1}$ Di dunia, 6 juta anak meninggal tiap tahun karena diare dan sebagian besar kejadian tersebut terjadi di negara berkembang. ${ }^{2}$ Sebagai gambaran $17 \%$ kematian anak di dunia disebabkan oleh diare. Di Indonesia diperoleh diare merupakan penyebab kematian bayi $42 \%$ dibanding pneumonia $24 \%$. Kematian golongan usia 1-4 tahun karena diare $25,2 \%$ dibandingkan pneumonia $15,5 \% .^{3}$

Hasil Riset Kesehatan Dasar (RISKESDAS) tahun 2007 menyatakan prevalensi nasional diare klinis (berdasarkan diagnosis tenaga kesehatan dan 
gejala) adalah 9,0\% dengan rentang 4,2\%-18,9\%. ${ }^{3}$ Dilaporkan 14 provinsi mempunyai prevalensi diare di atas prevalensi nasional, dengan prevalensi tertinggi terjadi di Aceh dan terendah di Yogyakarta. ${ }^{4}$ Di Aceh pada tahun 2008 proporsi kasus diare pada balita mencapai $44,5 \%$ yaitu dengan jumlah 58.116 kejadian, sedangkan pada tahun $2007,44,3 \% .^{5}$

Diare adalah buang air besar yang terjadi pada bayi dan anak yang sebelumnya nampak sehat, dengan frekuensi tiga kali atau lebih per hari, disertai perubahan tinja menjadi cair, dengan atau tanpa lendir dan darah. ${ }^{6}$ Apabila pada diare pengeluaran cairan melebihi pemasukan maka akan terjadi defisit cairan tubuh, maka akan terjadi dehidrasi. Berdasarkan derajat dehidrasi maka diare dapat dibagi menjadi diare tanpa dehidrasi, diare dehidrasi ringan sedang dan diare dehidrasi berat. Pada dehidrasi berat terjadi defisit cairan sama dengan atau lebih dari $10 \%$ berat badan. $^{7}$ Anak dan terutama bayi memiliki risiko yang lebih besar untuk menderita dehidrasi dibandingkan orang dewasa. ${ }^{8}$

Berdasarkan hasil penelitian Dwipoerwantoro9 tentang pola tata laksana diare akut di beberapa rumah sakit swasta di Jakarta pada tahun 1999, didapatkan bahwa 13\% dari seluruh penderita diare akut mengalami dehidrasi berat. Penelitian di Bali pada tahun 2004 mendapatkan 3\% pasien yang menderita diare akut dehidrasi berat, $58 \%$ mengalami asidosis metabolik, ensefalopati $47 \%$, hipernatremi $42 \%$, hiponatremi 18\%, dan hipokalemi $15 \% .^{10}$

Pada diare akut dengan dehidrasi berat, volume darah berkurang sehingga dapat terjadi dampak negatif pada bayi dan anak-anak antara lain syok hipovolemik (dengan gejala-gejalanya yaitu denyut jantung menjadi cepat, denyut nadi cepat, kecil, tekanan darah menurun, pasien lemah, kesadaran menurun, dan diuresis berkurang), gangguan elektrolit, gangguan keseimbangan asam basa, gagal ginjal akut, dan proses tumbuh kembang anak terhambat yang pada akhirnya dapat menurunkan kualitas hidup anak di masa depan. ${ }^{11,12}$

Dehidrasi memicu gangguan kesehatan, mulai dari gangguan ringan seperti mudah mengantuk, hingga penyakit berat seperti penurunan fungsi ginjal. ${ }^{13}$ Pada awalnya anak akan merasa haus karena telah terjadi dehidrasi ringan. Bila tidak ditolong, dehidrasi tambah berat dan timbulah gejala-gejala. Karena itu, pengobatan awal untuk mencegah dan mengatasi keadaan dehidrasi sangat penting pada anak dengan diare. ${ }^{14}$ Pemberian cairan yang tepat dengan jumlah yang memadai merupakan modal yang utama mencegah dehidrasi. Cairan harus diberikan sedikit demi sedikit dengan frekuensi sesering mungkin. ${ }^{15}$

Penyakit diare dapat mengakibatkan kematian bila dehidrasi tidak diatasi dengan baik. Sebagian besar diare pada anak akan sembuh sendiri (self limiting disease) asalkan dehidrasi dapat dicegah karena merupakan penyebab kematian. ${ }^{14}$

Malnutrisi seperti halnya diare, sering dijumpai pada anak-anak di negara-negara berkembang. Di Indonedsia, dengan adanya krisis ekonomi pada tahun 1997, angka kejadian diare dan malnutrisi menunjukkan kenaikan yang nyata.,16 Ditinjau dari penyakitnya, malnutrisi dapat merupakan komplikasi maupun faktor penyebab diare. Infeksi yang berkepanjangan, terutama pada diare, dapat menyebabkan penurunan asupan nutrisi, penurunan fungsi absorpsi usus, dan peningkatan katabolisme. Di sisi lain, pada malnutrisi terjadi penurunan proteksi barier mukosa usus yang meningkatkan kerentanan terhadap infeksi enteral. ${ }^{17,18}$

Berdasarkan uraian tersebut perlu dilakukan penelitian untuk mengetahui profil pasien diare di ruang rawat inap anak Bagian/SMF Ilmu Kesehatan Anak FK Unsiah/RSUDZA Banda Aceh.

\section{Metode}

Penelitian merupakan studi retrospektif melalui penelusuran berkas rekam medik pasien diare di ruang rawat inap anak Bagian/SMF Ilmu Kesehatan Anak FK Unsyiah/RSUDZA Banda Aceh dari tanggal 1 Juli 2009 s/d 30 Juni 2010. Pencatatan dilakukan pada umur, jenis kelamin, jenis diare, derajat dehidrasi, status gizi, penyakit penyerta dan lama rawatan dengan menempuh langkah-langkah pengumpulan data, klasifikasi, pengelohan/analisa data serta penyajian secara deskriptif. ${ }^{19,20}$ Penelitian bertujuan untuk melihat gambaran profil pasien diare di Ruang Rawat Inap Anak di RSUDZA Banda Aceh. Subjek penelitian adalah semua pasien bayi dan anak pada populasi yang memenuhi kriteria inklusi yaitu bayi usia $>1$ bulan 16 tahun yang dirawat dengan diare. Diagnosis diare dibuat berdasarkan kriteria klinis, yaitu (1) frekuensi buang air besar lebih dari tiga kali dalam 24 jam, dan (2) perubahan konsistensi tinja menjadi lebih cair. Kriteria kesembuhan ditentukan berdasarkan, (1) berkurangnya frekuensi diare menjadi kurang dari tiga per hari, (2) konsistensi tinja yang makin padat, serta (3) keadaan 
umum dan asupan makanan pasien membaik.

Status gizi ditentukan dengan menghitung berat badan pasien saat sakit dibandingkan terhadap berat badan ideal menurut umur. Sebelum dibandingkan, berat badan ditambah menurut derajat dehidrasinya, yaitu penambahan $7,5 \%$ pada dehidrasi ringan sedang, dan $10 \%$ pada dehidrasi berat (RSUD Dr.Soetomo, 2008). Berdasarkan berat badan, status gizi digolongkan menjadi 5 kategori (1) gizi buruk apabila persen berat badan $<60 \%$, gizi kurang $60 \%$ $79 \%$, gizi normal 80\%-110\%, gizi lebih $111 \%-120 \%$, dan obesitas apabila persen berat badan $>120 \% .{ }^{21}$

Lama hari rawat ditentukan berdasarkan lama hari mulai pasien masuk sampai dengan keluar rumah sakit. Lama hari rawat digolongkan menjadi, hari rawat kurang dari 5 hari dan lebih/sama dengan 5 hari. Batasan tersebut ditentukan atas dasar rata-rata lama hari rawat inap yang dihubungkan dengan batasan jangka waktu diare akut yaitu kurang dari 7 hari. ${ }^{22}$ Diare melanjut yaitu diare yang berlangsung antara 7-14 hari, sedangkan bila lebih dari 14 hari disebut diare persisten. ${ }^{23}$ Penyakit penyerta adalah penyakit lain yang dialami oleh pasien saat masuk perawatan di rumah sakit.

\section{Hasil}

Jumlah pasien rawat inap di ruang rawat anak Bagian/ SMF Ilmu Kesehatan Anak Fakultas Kedokteran Unsyiah/ RSUZA Banda Aceh periode 1 Juli 2009 sampai 30 Juni 2010, adalah 1279 orang, 104 (8,1\%) anak diantaranya menderita diare. Karakteristik umur pasien dibagi menjadi tiga kategori yaitu umur 1 bulan $-<2$ tahun, umur $2-<5$ tahun, dan $5-16$ tahun (Tabel 1).

Jumlah pasien yang berusia 1 bulan $-<2$ tahun $76(73,1 \%)$ pasien, umur $2-<5$ tahun $19(18,3 \%)$ pasien, dan umur $5-16$ tahun $9(8,6 \%)$ pasien. Pasien berjenis kelamin laki-laki $50(48,1 \%)$ pasien dan jenis kelamin perempuan $54(51,9 \%)$ pasien. Berdasarkan jenis diare dibagi menjadi tiga kategori yaitu diare akut $84(80,8 \%)$, diare melanjut 13 (12,5\%), dan diare persisten 7 (6,7\%) pasien. Derajat dehidrasi dibagi menjadi tiga yaitu tanpa dehidrasi 27 (26\%), dehidrasi ringan sedang $65(62,5 \%)$, dan dehidrasi berat 12 $(11,5 \%)$ pasien (Tabel 2).

Tabel 2 memperlihatkan status gizi, obesitas 6 $(5,8 \%)$, gizi lebih $3(2,9 \%)$, gizi normal $46(44,2 \%)$, gizi kurang $40(38,5 \%)$, dan gizi buruk $9(8,6 \%)$ pasien. Pada pasien diare yang disertai dengan penyakit penyerta didapatkan $58(55,8 \%)$ pasien, berturutturut $40(68,9 \%)$ menderita gizi kurang, $9(15,5 \%)$ dengan gizi buruk, 4 (6,9\%) bronkopneumonia, $2(3,5 \%)$ tonsilofaringitis akut, $2(3,5 \%)$ kejang demam kompleks, dan 1 (1,7\%) menderita varisela. Berdasarkan lama rawatan dari 104 pasien diare sebagian besar didapatkan kurang dari 5 hari yaitu 94 (90,4\%) pasien.

Tabel 1. Karakteristik subjek diare

\begin{tabular}{lcc}
\hline Distribusi ( $\mathrm{n}=104)$ & Frekuensi & $\%$ \\
\hline Umur & & \\
1 bulan $-<2$ tahun & 76 & 73,1 \\
$2-<5$ tahun & 19 & 18,3 \\
$5-16$ tahun & 9 & 8,6 \\
Jenis kelamin & & \\
$\quad$ Laki-laki & 50 & 48,1 \\
$\quad$ Perempuan & 54 & 51,9 \\
Status gizi & & \\
Obesitas & 6 & 5,8 \\
Gizi lebih & 3 & 2,9 \\
Gizi normal & 46 & 44,2 \\
Gizi kurang & 40 & 38,5 \\
Gizi buruk & 9 & 8,6 \\
\hline
\end{tabular}

Tabel 2. Karakteristik diare

\begin{tabular}{lcc}
\hline Distribusi (n=104) & Frekuensi & $\%$ \\
\hline & & \\
Jenis diare & & \\
$\quad$ Akut & 84 & 80,8 \\
$\quad$ Melanjut & 13 & 12,5 \\
$\quad$ Persisten & 7 & 6,7 \\
Derajat dehidrasi & & \\
$\quad$ Tanpa dehidrasi & 27 & 26 \\
$\quad$ Dehidrasi ringan sedang & 65 & 62,5 \\
$\quad$ Dehidrasi berat & 12 & 11,5 \\
Penyakit penyerta & & \\
$\quad$ Disertai penyakit penyerta & 58 & 55,8 \\
$\quad$ Gizi kurang & 40 & 68,9 \\
$\quad$ Gizi buruk & 9 & 15,5 \\
$\quad$ Bronkopneumonia & 4 & 6,9 \\
$\quad$ Tonsilofaringitis akut & 2 & 3,5 \\
$\quad$ Kejang demam komplek & 2 & 3,5 \\
$\quad$ Varisela & 1 & 1,7 \\
Lama rawatan (hari) & & \\
$\quad<5$ & 94 & 90,4 \\
$\quad$ 25 & 10 & 9,6 \\
\hline
\end{tabular}




\section{Pembahasan}

Angka kesakitan maupun angka kematian pada hampir semua keadaan menunjukkan berhubungan dengan umur. Sesuai dengan hasil penelitian Sinthamurniwaty ${ }^{24}$ tahun 2006, didapatkan kelompok umur terbanyak menderita diare kurang dari 24 bulan $(58,68 \%)$, diikuti $24-36$ bulan $(24,65 \%)$, sedangkan paling sedikit umur 37-60 bulan (16,67\%). Balita umur $<24$ bulan mempunyai risiko 3,18 kali terkena diare akut dibandingkan $>24$ bulan. Begitu juga dengan hasil penelitian Mendrofa ${ }^{25}$ tahun 2006, didapatkan proporsi terbesar balita pasien diare berumur $1-<3$ tahun $(46,8 \%)$ dan proporsi terendah pada umur $3-<5$ tahun (19\%).

Umur ada kaitannya dengan daya tahan tubuh. Pada umumnya daya tahan tubuh dewasa jauh lebih tinggi dari pada daya tahan tubuh bayi dan anak. ${ }^{26}$ Angka kesakitan pada bayi dan anak berhubungan dengan daya tahan tubuhnya sehingga anak dan terutama bayi memiliki risiko yang lebih besar untuk menderita diare dan dehidrasi dibandingkan orang dewasa. ${ }^{8}$

Penelitian Mendrofa ${ }^{25}$ mendapatkan prevalensi diare pada balita perempuan sedikit lebih tinggi dibandingkan pada balita laki-laki. Di luar negeri angka kesakitan lebih tinggi pada kalangan perempuan sedangkan angka kematian lebih tinggi pada kalangan laki-laki juga pada semua golongan umur. Untuk Indonesia masih perlu dipelajari lebih lanjut. Perbedaan angka kematian ini, dapat disebabkan oleh faktor-faktor intrinsik. ${ }^{26}$ Berbeda dengan penelitian yang dilakukan Jurnalis ${ }^{12}$ jenis kelamin laki-laki lebih banyak dari perempuan $(75,9 \%$ vs $24,1 \%)$, sedangkan berdasarkan penelitian Mahalini ${ }^{10}$ pada tahun 2004 di Bali juga mendapatkan kasus dengan jenis kelamin laki-laki lebih banyak dari perempuan (60\% vs 40\%). Pada kasus tertentu jenis kelamin mempengaruhi terjadinya penyakit akan tetapi pada penelitian ini jenis kelamin tidak memberikan perbandingan yang jauh berbeda. Pada kasus diare jenis kelamin tidak mempengaruhi kejadian diare.

Berdasarkan hasil penelitian kami didapatkan pasien diare paling banyak mengalami diare dengan dehidrasi ringan sedang. Pada diare, dehidrasi menyebabkan penurunan volume cairan tubuh yang menyebabkan berkurangnya perfusi jaringan. Berkurangnya volume sirkulasi menyebabkan peningkatan kecepatan nadi sebagai kompensasi karena jantung berusaha untuk meningkatkan keluaran (output) dalam menghadapi volume pukulan (stroke volume) yang berkurang.
Berkurangnya perfusi jaringan juga menghambat fungsi ginjal sehingga menyebabkan asidosis dan uremia (pada diare asidosis diperberat dengan kehilangan bikarbonat). Penyampaian oksigen pada jaringan menyebabkan pula asidosis laktat. Apabila terdapat pengurangan dalam pemasukan kalori yang menyertainya atau ketidakmampuan untuk menstabilisasi kalori yang masuk, dapat timbul ketoasidosis. ${ }^{27}$

Diare akut merupakan jenis diare terbanyak diikuti oleh diare melanjut dan diare persisten. Hal tersebut hampir sesuai dengan literatur bahwa kejadian diare akut didapatkan $80 \%$, dan diare melanjut lebih kurang $15 \%$, sedangkan yang menjadi diare persisten sebanyak 5\%. ${ }^{28}$ Dari delapan studi komunitas di Asia dan Amerika Latin didapati persentase diare persisten antara 3\%-23\% dari seluruh kasus diare. Pada tujuh studi lainnya insiden diare persisten sangat bervariasi. Di India insiden diare persisten sekitar 7 kasus tiap 100 anak pertahun. Pada seluruh studi insiden tertinggi pada anak di bawah 2 tahun. Data WHO dan UNICEF memperkirakan pada tahun 1991 diare persisten terjadi 10\% dari episode diare dengan kematian sebanyak 35\% pada anak dibawah 5 tahun. Studi di Bangladesh, India, Peru, dan Brazil mendapatkan kematian sekitar $45 \%$ atau 30\%-50\% kematian dari diare persisten. ${ }^{29,30}$ Meskipun insiden diare persisten paling banyak terjadi pada anak di bawah 2 tahun, namun kematian sering terjadi pada anak 1-4 tahun ketika malnutrisi sering timbul. Hal tersebut dikarenakan kematian oleh diare persisten sering berhubungan dengan malnutrisi. ${ }^{30}$

Diare dan malnutrisi secara tunggal atau bersamasama, merupakan penyebab utama morbiditas dan mortalitas pada anak-anak di negara tropis. Data dari Timur Laut Brazilia, menunjukkan bahwa diare adalah akibat sekaligus penyebab dari dari malnutrisi. ${ }^{31} \mathrm{Pada}$ penelitian Primayani, ${ }^{21}$ jumlah pasien diare dengan status gizi normal dan kurang yang menjalani rawat inap kurang dari lima hari adalah lebih besar dari jumlah anak yang menjalani rawat inap lebih/sama dengan lima hari. Sebaliknya, pada kelompok gizi buruk, jumlah pasien rawat inap kurang dari lima hari lebih sedikit dari pada yang dirawat lebih dari lima hari. Meskipun demikian, kecenderungan ini tidak terbukti secara statistik. ${ }^{21}$ Pada penelitian kami, pasien diare disertai dengan gizi buruk didapatkan $8,6 \%$ dan gizi kurang 38,5\%. Lama rawatan yang melebihi/sama dengan lima hari adalah 9,6\%, apakah ini ada hubungannya dengan status gizi atau derajat 
dehidrasi dari pasien, tentu memerlukan penelitian analitik lebih lanjut.

Hubungan diare dan malnutrisi, seperti dilaporkan oleh Scrimshaw, Taylor, dan Gordon pada tahun 1968, adalah dua arah. Infeksi mengubah status nutrisi melalui penurunan asupan makanan dan absorpsi usus, peningkatan katabolisme, dan sekuestrasi nutrisi yang diperlukan untuk sintesa jaringan dan pertumbuhan. Di sisi lain, malnutrisi membuka predisposisi pada dampak infeksi karena negatif pada pertahanan mukosa dengan jalan memicu perubahan pada fungsi imunitas pejamu (Brown). ${ }^{32}$

Anak yang menderita diare mungkin juga disertai dengan penyakit lain. Dalam menangani diare juga perlu diperhatikan penyakit penyerta yang menyertai. Beberapa penyakit penyerta yang sering terjadi bersamaan dengan diare antara lain infeksi saluran nafas, infeksi susunan saraf pusat, infeksi saluran kemih, infeksi sistemik lain (sepsis, campak), kurang gizi, penyakit jantung, dan penyakit ginjal. ${ }^{33}$ Pada temuan kami dari 104 pasien diare terdapat 58 $(55,8 \%)$ pasien disertai dengan penyakit penyerta, yaitu terbanyak gizi kurang dan gizi buruk, sedangkan lainnya adalah bronkopneumonia, tonsilofaringitis akut, kejang demam kompleks, dan varisela.

\section{Daftar pustaka}

1. Lukacik M, Ronald L, Thomas, Jacob VA. A metanalysis of the effect of oral zinc in the treatment of acute and persistent diarrhea. 2007. Diunduh dari: http://www.pediatrics.org/cgi/ content/full/121/2/326, diakses tanggal 24-10-2010.

2. Parashar UD, Hummelman EG, Breese JS, Miller MA, Glass RI. Global Illnes and death caused by rotavirus diseases in children. Emerging infection diseases;2006.9:565-72.

3. Riskesdas, www.scribd.com/doc/31834110/IndonesiaRiskesdas-2007. tanggal 7 Februari 2011.

4. Departemen Kesehatan RI. Profil Kesehatan Indonesia 2008. Jakarta. 2009.

5. Dinas Kesehatan Aceh. Profil Kesehatan Provinsi Nanggroe Aceh Darussalam Tahun 2009. Aceh. 2009.

6. Markum AH. Saluran cerna. Dalam: Buku ajar Ilmu Kesehatan Anak. Jilid 1. Jakarta: FKUI. 2009.

7. Departemen Kesehatan RI. Buku Ajar Diare: Pendidikan medik pemberantasan diare. Jakarta: Ditjen. PPM dan PLP 1999.
8. Rudolph JA, Rufo PA. Diarrhea. Dalam: Benson JB, Haith MM, penyunting. Disease and disorder in infancy and early childhood. Edisi pertama Elsevier. San Diego. 2004. h.130-7.

9. Dwipoerwantoro PG, Badriul Hegar, Pustika A.W. Pola tatalaksana diare akut di beberapa rumah sakit swasta di Jakarta; apakah sesuai dengan protocol WHO? Sari Pediatri 2005;6:182-7.

10. Mahalini DS, Aryasa IKN, Suraatmaja S. (Abstr). Gangguan elektrolit dan keseimbangan asam basa pada diare akut dehidrasi berat. Abstrak disampaikan pada Pertemuan Ilmiah Tahunan Ilmu Kesehatan Anak II. Batam, 12-14 Juli 2004.

11. Latief A, dkk. Buku Kuliah Ilmu Kesehatan Anak. Jilid I dan II. Edisi 11. Bagian Ilmu Kesehatan Anak FKUI. Jakarta. 2007.

12. Jurnalis YD, Sayoeti Y, Dewi S. Profil Gangguan Elektrolit dan Keseimbangan Asam Basa Pada Pasien Diare Akut Dengan Dehidrasi Berat di Ruang Rawat Inap Bagian Anak RS dr. M. Djamil Padang. Majalah Kedok Andalas 2008;1:32.

13. Noorastuti PT, Nugraheni M. Kenali bahaya dehidrasi kekurangan cairan tubuh sekitar dua persen sudah memicu gangguan kesehatan. 2010. Diunduh dari: http://www.vivanews.com/news/read/153985-kenali bahaya dehidrasi. Diakses tanggal 2 Februari 2011.

14. IDAI. Pencegahan dan pengobatan diare pada anak di rumah. 2009. Diunduh dari: http://www.idai.or.id/ kesehatananaklartikel.asp?q=200741515310. Diakses pada 2 Februari 2011.

15. Agustina M. Asuhan keperawatan pada anak dengan gangguan system pencernaan: Diare di bangsal Anggrek RSUD Sukoharjo. Skripsi. Universitas Muhammadiah Surakarta. 2008.

16. Black RE, Brown $\mathrm{KH}$, Becker S.. Malnutrition is a determining factor in diarrheal duration, but not incidence, among young children in a longitudinal study in rural Bangladesh. Am J of Clin Nutr 1984;39:87-94.

17. Brown KH. Diarrhea and malnutrition. Prosiding symposium: nutrition in infection, prologue and progress since 1968; Am Soc for Nutr Sci; 2003.

18. Harohalli RS, Donna GG. Malnutrition. eMedicine. 2009. Didapatkan dari: URL:http://emedicine, medscape.com/ article/985140-overview.diakses tanggal 7 Februari 2011.

19. Notoatmodjo, S. Metodologi Penelitian Kesehatan. Edisi 3. Rineka Cipta. Jakarta. 2005.

20. Praktiknya, AW. Dasar-dasar metodologi penelitian kedokteran dan kesehatan. PT. Raja Grafindo Persada. Jakarta. 2008. 
21. Primayani D. Status gizi pada pasien diare akut di ruang rawat inap anak RSUD SoE Kabupaten Timor tengah Selatan, NTT. Sari Pediatri;2009:11: 90-3.

22. RSUD Dr. Soetomo. Pedoman diagnosis dan terapi Bagian/SMF Ilmu Kesehatan Anak RSUD Dr. Soetomo, Edisi ke-3.h.2-4.

23. Juffrie M, Mulyani NS. Modul pelatihan diare. UKK Gastro-hepatologi IDAI, Edisi pertama. Jakarta 2009.

24. Sinthamurniwaty. Faktor-faktor risiko kejadian diare akut pada balita. Skripsi. Universitas Diponegoro Semarang. 2006.

25. Mendrofa K. Karakteristik balita penderita diare yang berobat di Puskesmas Tetehosi Foa Kecamatan Gido Kabupaten Niasa tahun 2005. Skripsi. Universitas Sumatera Utara, Medan, 2006.

26. Jannah, R. Gambaran penderita diare serta karakteristik yang berobat pada bulan juli di puskesmas peusangan kabupaten bireun tahun 2005. Skripsi. Universitas Muhammadiyah Aceh, 2005.

27. Irwanto, Rohim A, Sudarmo SM. Diare akut pada anak. Dalam: Soeginjato, S, penyunting. Ilmu penyakit anak diagnosa dan penatalaksanaan. Penerbit Salemba Medika. Jakarta; 2002.h.73-91.

28. Yusuf S. Diare persisten. JGAI 2007;1: 6-23.

29. WHO. Pelayanan kesehatan anak di rumah sakit pedoman bagi rumah sakit rujukan tingkat pertama di kabupaten/kota. WHO dan Departemen Kesehatan RI. Jakarta. 2009.

30. Putra DS. Diare akut pada anak. Upaya mengurangi kejadian komplikasi diare akut. 2008. Di unduh dari: http://www.dr-rocky.com/layout-artikel-kesehatan/42-diare-akutpada-anak. Diakses tanggal 7 Februari 2011.

31. Guerrant RL. Diarrhea as a cause and an effect of malnutrition increase diarrhea frequency and duration. Am J Trop Med Hyg;1992;47:28-35.

32. Brown KH. Diarrhea and malnutrition. Prosiding symposium: nutrition in infection, prologue and progress since 1968; Am Soc for Nutr Sci 2003.

33. Anonimos. Penatalaksanaan gastroenteritis pada balita. 2011. Diunduh dari: http://www.dr-rocky.com/layoutartikel-kesehatan/42-diare-akut-pada-anak, diakses tanggal 7 Februari 2011. 